\title{
Sol-Gel Derived Ti-Fe Oxide Coating for Photoelectrochemical Cathodic Protection of Carbon Steel
}

\author{
Jianshun Huang*,**, Tomoyoshi Konishi*, Tadashi Shinohara* and Shigeo Tsujikawa* \\ * Department of Metallurgy, School of Engineering, The University of Tokyo \\ ** Shanghai Institute of Metallurgy, Chinese Academy of Science
}

\begin{abstract}
On the novel approach of corrosion protection of carbon steel by $\mathrm{TiO}_{2}$ coating under illumination, photoeffect of $\mathrm{TiO}_{2} / \mathrm{C}$-steel system is affected by the structural and electronic properties of the interfacial $\mathrm{Ti}-\mathrm{Fe}$ oxide. In the present work, $\mathrm{Ti}-\mathrm{Fe}$ oxide with a wide range of composition, from $\mathrm{TiO}_{2}$ to $\alpha-\mathrm{Fe}_{2} \mathrm{O}_{3}$, was prepared by sol-gel method. By studying the characteristics of the $\mathrm{Ti}-\mathrm{Fe}$ oxides and their influences on the photoeffect of $\mathrm{TiO}_{2} / \mathrm{C}$ steel system, a multi-layer coating, expressed as from outer coating layer to substrate: $\mathrm{TiO}_{2}$ (amorphous) $/ \mathrm{TiO}_{2}$ (anatase) $/ \mathrm{Ti}-\mathrm{Fe}$ oxide $/ \alpha-\mathrm{Fe}_{2} \mathrm{O}_{3} / \mathrm{C}$-steel, was proposed for more ef fective photoelectrochemical cathodic protection of carbon steel. $\mathrm{TiO}_{2}$ (anatase) layer without $\mathrm{Fe}$ contamination exhibits a good photoeffect and behaves like the source of photo-excited electrons. The inner $\alpha-\mathrm{Fe}_{2} \mathrm{O}_{3}$ layer acts as both a barrier to retard the diffusion of $\mathrm{Fe}$ into $\mathrm{TiO}_{2}$ and a way for the transfer of photo-excited electrons from the $\mathrm{TiO}_{2}$ (anatase) coating to the substrate. The outer layer of amorphous $\mathrm{TiO}_{2}$ inhibits the oxygen reduction and reduces the photopotential to a more less noble value. The intermediate layer of amorphous $\mathrm{Ti}-\mathrm{Fe}$ oxide provides deep levels for $\mathrm{Fe}^{2+} / \mathrm{Fe}^{3+}$ redox couple, for which $\mathrm{Fe}^{3+}$ is reduced to $\mathrm{Fe}^{2+}$ by the photo-excited electrons under illumination. The state of $\mathrm{Fe}^{2+}$ left after stopping illumination contributes to phenomenon that the electrode potential is maintained at considerably less noble value until all the $\mathrm{Fe}^{2+}$ is re-oxidized by oxygen reduction.
\end{abstract}

Key words: corrosion, cathodic protection, photoelectrochemistry, $\mathrm{TiO}_{2}$, Ti-Fe oxides, carbon steel, photoeffect, sol-gel method.

\section{Introduction}

Metal is expected to be protected against corrosion by a coating, which can absorb solar energy, transform it to electricity and store the electric energy up so as to protect the substrate metal functionally. The studies ${ }^{1) \sim 7)}$ on corrosion protection of metal by $\mathrm{TiO}_{2}$ coating under illumination promise such a novel approach. With high chemical stability and a moderate flat-band potential, $\mathrm{TiO}_{2}$ coating under illumination acts as a non-sacrificial anode and protects substrate metal cathodically even with presence of coating defects. In addition, potential after stopping illumination was observed to recover slowly from photopotential to its original value before illumina-

* 7-3-1, Hongo, Bunkyo-ku, Tokyo, 113-0061 Japan

** 865 Changning Road, Shanghai, China tion. This phenomenon shows promise that photoeffect can be remained even after stopping illumination.

On corrosion protection of carbon steel by $\mathrm{TiO}_{2}$ coating, photoeffect of $\mathrm{TiO}_{2} /$ Carbon steel (C-steel) system had been shown to be affected by structural and electronic properties of the interfacial oxides, i.e., iron oxides and $\mathrm{Ti}-\mathrm{Fe}$ oxides at the $\mathrm{TiO}_{2} / \mathrm{C}$-steel interface. As shown in our previous work ${ }^{5)}$, a good photoeffect was observed for $\alpha-\mathrm{Fe}_{2} \mathrm{O}_{3}$ while poor for $\mathrm{Fe}_{3} \mathrm{O}_{4}$ and $\gamma-\mathrm{Fe}_{2} \mathrm{O}_{3}$. The photoeffect of $\mathrm{TiO}_{2} /$ $\mathrm{C}$-steel was also observed to be deteriorated by diffusion of $\mathrm{Fe}$ into $\mathrm{TiO}_{2}$. Recently, the phenomenon of slower recovery of electrode potential after stopping illumination has been found to be related to $\mathrm{Fe}$ doped in $\mathrm{TiO}_{2}$ by Konishi and Tsujikawa ${ }^{7)}$. Thus it is imperative to examine the characteristics of Ti-Fe 
oxides and their influences on the photoeffect of $\mathrm{TiO}_{2} / \mathrm{C}$-steel system. In the present work, $\mathrm{Ti}-\mathrm{Fe}$ oxide with a wide range of composition, from $\mathrm{TiO}_{2}$ to $\alpha-\mathrm{Fe}_{2} \mathrm{O}_{3}$, were prepared by sol-gel method and their structural, electrochemical and photoelectrochemical behavior were examined. Based upon this, a multi-layer coating was proposed for the corrosion protection of carbon steel under illumination. The photoelectrochemical reactions and the function of each layer on the performance of photoeffects were discussed. Particular attention was focused on the phenomenon of the slower recovery of the electrode potential after stopping illumination.

\section{Experimental}

Two kinds of substrate specimens were used; carbon steel and tin-doped indium oxide (ITO). The carbon steel sheets (mass\%: C 0.111 , Si 0. 013, Mn 0.367, P 0.015, S 0. 0056, Al $0.120, \mathrm{Fe}$ bal.) of $0.8 \mathrm{~mm}$ thickness were mechanically cut to a size of $25 \times 25 \mathrm{~mm}$ and polished to a mirror finish by $0.05 \mu \mathrm{m} \mathrm{Al}_{2} \mathrm{O}_{3}$. The dimension of ITO $\left(600 \AA, \mathrm{In}_{2} \mathrm{O}_{3}-10\right.$ mass $\% \mathrm{SnO}_{2}$ on glass, $\left.39 \Omega / \square\right)$ was also $25 \times 25$ $\mathrm{mm}$. Prior to coating, all steel and ITO substrates were ultrasonically cleaned in acetone and dried.

The sols for Ti-Fe oxides were obtained through mixing the two kinds of sols, given in

Table 1 The two kinds of sols for preparation of $\alpha-\mathrm{Fe}_{2} \mathrm{O}_{3}$, $\mathrm{TiO}_{2}$ and $\mathrm{Ti}-\mathrm{Fe}$ oxide.

\begin{tabular}{|c|c|c|}
\hline Composition Sols & $\begin{array}{r}\text { Sol for } \mathrm{Fe}_{2} \mathrm{O}_{3} \\
(0.02 \text { mole })\end{array}$ & $\begin{array}{l}\text { Sol for } \mathrm{TiO}_{2} \\
(0.05 \mathrm{~mole})\end{array}$ \\
\hline $\begin{array}{l}\text { Titamum Tetraisopropoxide } \\
\mathrm{Ti}(\mathrm{OCH}(\mathrm{CH} 3)) 4 \quad(284.23)\end{array}$ & & $14.2 \mathrm{~g}$ \\
\hline $\begin{array}{l}\mathrm{Fe}^{3+} \text { Nitrate Enneahydrate } \\
\mathrm{Fe}\left(\mathrm{NO}_{3}\right) 3.9 \mathrm{H}_{2} \mathrm{O}(404.00)\end{array}$ & $8.08 \mathrm{~g}$ & \\
\hline $\begin{array}{l}\text { Nitric Acid } \\
\mathrm{HNO}_{3} \quad(63.01)\end{array}$ & & $0.3 \mathrm{~g}$ \\
\hline $\begin{array}{l}\text { 2.4-Pentandione } \\
\mathrm{CH}_{3} \mathrm{COCH}_{2} \mathrm{COCH}_{3}(100.12)\end{array}$ & $1.0 \mathrm{~g}$ & \\
\hline $\begin{array}{c}\text { Ethanol } \\
\mathrm{C}_{2} \mathrm{H}_{5} \mathrm{OH}(46.07)\end{array}$ & $26.0 \mathrm{~g}$ & $34.7 \mathrm{~g}$ \\
\hline $\begin{array}{c}\text { 2-Methoxyethanol } \\
\mathrm{CH}_{3} \mathrm{OCH}_{2} \mathrm{CH}_{2} \mathrm{OH}(76.10)\end{array}$ & $15.0 \mathrm{~g}$ & \\
\hline $\begin{array}{l}\text { Water* } \\
\mathrm{H}_{2} \mathrm{O}(18)\end{array}$ & & $0.8 \mathrm{~g}$ \\
\hline
\end{tabular}

* not added for Ti-Fe oxide, but only for pure $\mathrm{TiO}_{2}$
Table $1^{8) \sim 10)}$, according to $\mathrm{Fe} / \mathrm{Ti}$ mole ratios. The sols were kept stirring at $0^{\circ} \mathrm{C}$ while they were dissolved and mixed. All coating films were prepared on substrates by dip-coating method. The dip-coating was dried at room temperature for $10 \mathrm{~min}$, and then heated at $200^{\circ} \mathrm{C}$ for $10 \mathrm{~min}$ for each dip procedure. To increase the coating thickness, the above procedure was repeated several times, and finally heat-treated at different temperatures for 10 min.

The photoelectrochemical measurements were conducted usually under illumination of a $500 \mathrm{~W}$ high pressure $\mathrm{Hg}$ lamp. However, the photo spectra from 300 to $800 \mathrm{~nm}$ wave-lengths were recorded with the illumination setup of a $150 \mathrm{~W}$ Xenon lamp combined with a monochromator. A three electrode electrochemical cell was used, and it consisted of acryl container with a quartz window on one side and an opening on the opposite side to which the sample was fitted using a rubber O-ring. The area of the sample exposed to the electrolyte was $0.78 \mathrm{~cm}^{2}$. The electrolyte was $1 \mathrm{~m} \mathrm{~mol} / \mathrm{dm}^{3}$ $\mathrm{NaHCO}_{3}$, and $\mathrm{pH} 11$ was adjusted with concentrated $\mathrm{Na}_{2} \mathrm{CO}_{3}$ solution. Polarization curves were measured by a potential sweep beginning at the spontaneous electrode potential with a scanning rate of $25 \mathrm{mV} / \mathrm{min}$. For the measurements of cyclic voltammetry, a potential scan rate of $5 \mathrm{mV} / \mathrm{s}$ was used. The electrode potential was referred to a saturated calomel electrode (SCE).

Without specification, all the experiments were carried out in aerated condition. For deaerated condition, the solutions were thoroughly purged with $99.99 \%$ nitrogen gas. The electrochemical experiments were conducted at room temperature.

The crystallographic characteristics of Ti-Fe oxides prepared under different conditions were determined by the $\mathrm{X}$-ray diffraction using a $\mathrm{Cu} \mathrm{K} \alpha$ beam $(40 \mathrm{kV}, 200 \mathrm{~mA})$.

\section{Results and Discussion}

\section{1 Preparation and structural characteristics}

Fig. 1 shows the XRD patterns of Ti-Fe oxide powder specimens heat-treated at $400^{\circ} \mathrm{C}$ for $10 \mathrm{~min}$. The 


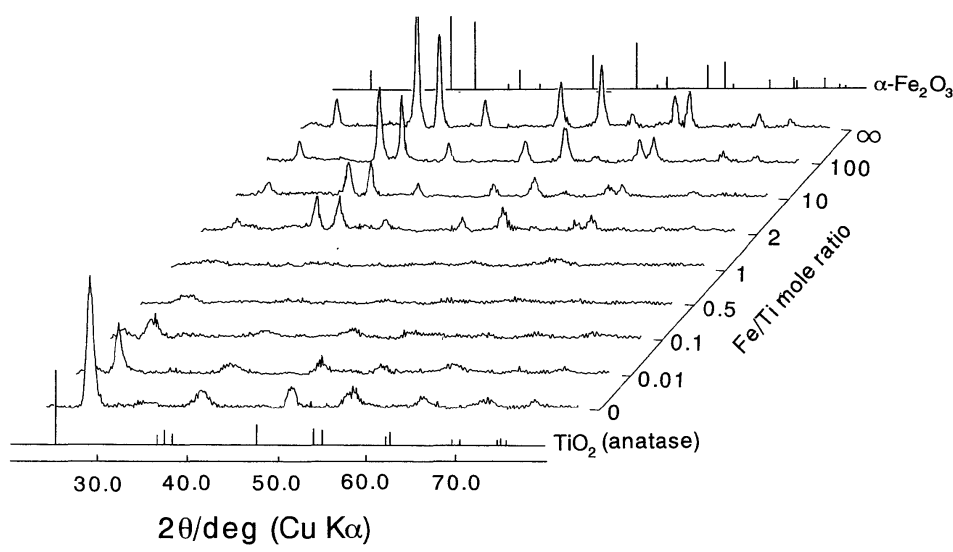

Fig.1 The XRD patterns of Ti-Fe oxide powder specimens with different composition heat treated at $400^{\circ} \mathrm{C}$ for $10 \mathrm{~min}$.

$\alpha-\mathrm{Fe}_{2} \mathrm{O}_{3}(\mathrm{~h})$, pseudobrookite (p) and rutile(r) phases were detect$\mathrm{ed}^{8)}$. For the specimen finally heat-treated below $300^{\circ} \mathrm{C}$, there existed an almost exclusive amorphous phase for relatively high $\mathrm{Ti}$ content compositions while an additional weak pattern of spinel structure $\left(\gamma-\mathrm{Fe}_{2} \mathrm{O}_{3}\right)$ was observed for relatively high $\mathrm{Fe}$ content compositions.

\section{2 Electrochemical and photo- electrochemical properties}

\section{2. 1 Photoeffect}

The anodic polarization curves of $\mathrm{Ti}-\mathrm{Fe}$ oxide under illumination are shown in Fig. 3 . The pho-

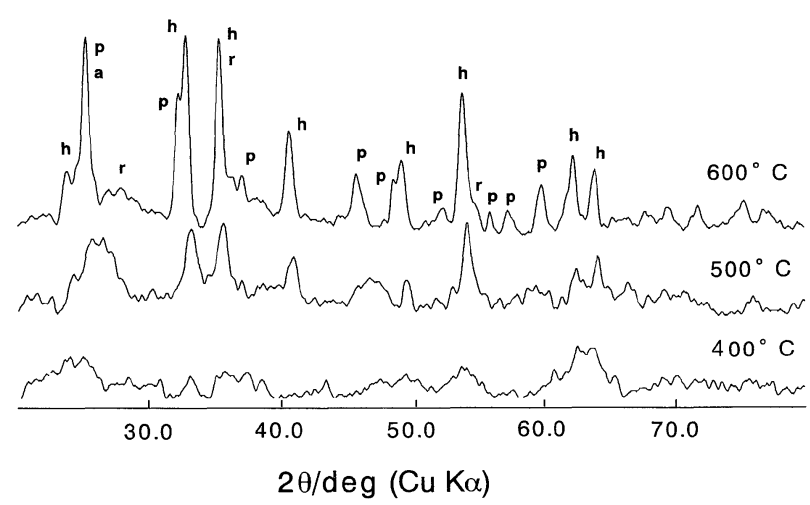

Fig.2 The variation of the XRD patterns with heat treatment temperature for the composition with the $\mathrm{Fe} / \mathrm{Ti}$ mole ratio of 1 . (h--hematite $\left(\alpha-\mathrm{Fe}_{2} \mathrm{O}_{3}\right)$; a--anatase; p--pseudobrookite; r--rutile).

powder were prepared from the sol mixtures same to the dip-coated specimen. Thick films dip-coated on quartz substrates behaved similarly. As determined from the XRD analysis, a series of solid solution compounds of Ti-Fe oxides, from pure $\mathrm{TiO}_{2}$ (anatase) to pure $\alpha-\mathrm{Fe}_{2} \mathrm{O}_{3}$, were obtained. It was found from the XRD patterns that amorphous character appeared at intermediate range of composition with $\mathrm{Fe} / \mathrm{Ti}$ mole ratio near 1 . Fig. 2 shows the variation of the XRD patterns with heat treatment temperature for the composition with the $\mathrm{Fe} / \mathrm{Ti}$ mole ratio of 1 . With increasing the temperature for heat-treatment from $400^{\circ} \mathrm{C}$ to $600^{\circ} \mathrm{C}$, the original amorphous phase were transformed to new crystalline phases. In addition to the anatase (a) and the tocurrent decreased significantly with increasing $\mathrm{Fe}$ content in $\mathrm{TiO}_{2}$, for example, by near one third in magnitude for $\mathrm{Fe} / \mathrm{Ti}$ mole ratio of 0.01 . The photocurrent for pure $\alpha-\mathrm{Fe}_{2} \mathrm{O}_{3}$ was also detected but the beginning is the higher potential than that of $\mathrm{TiO}_{2}$. Photocurrent spectra were measured for different compositions from $\mathrm{TiO}_{2}$ to $\alpha$ $\mathrm{Fe}_{2} \mathrm{O}_{3}$. The spectra are shown in Fig. 4 where they are normalized to equal maxima. From the onset of the photocurrent on the lower side of photon energy, it is found that the band gap energies are near 3.0 and $2.2 \mathrm{eV}$ for the pure $\mathrm{TiO}_{2}$ and the pure $\alpha$ $\mathrm{Fe}_{2} \mathrm{O}_{3}$, respectively. Both $\mathrm{Fe}$-doped $\mathrm{TiO}_{2}$ and Ti-doped $\alpha-\mathrm{Fe}_{2} \mathrm{O}_{3}$ resulted in a shift of the onset energy to longer wavelength, i.e., lower photon energy. A broad absorption

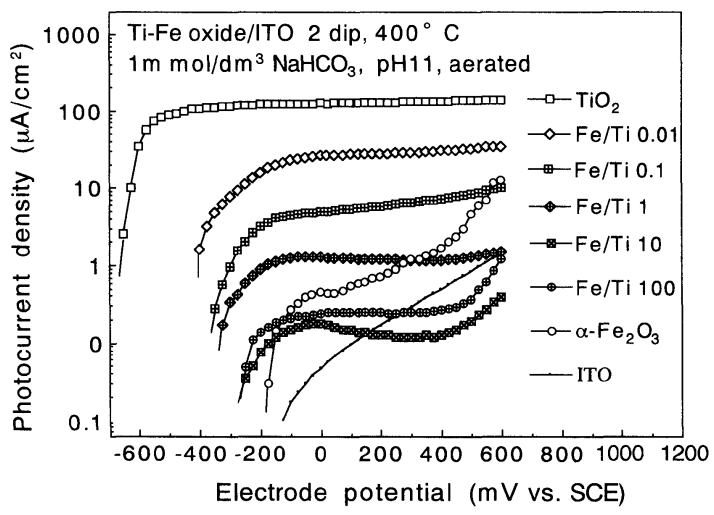

Fig.3 The anodic polarization curves under illumination of $\mathrm{Ti}-\mathrm{Fe}$ oxides with different compositions. 


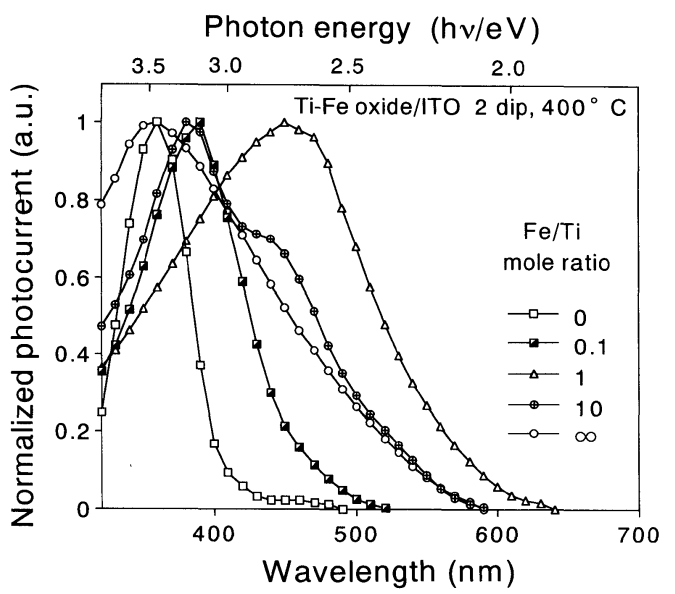

Fig.4 The photocurrent spectra of Ti-Fe oxides with different compositions. It was normalized to equal maxima.

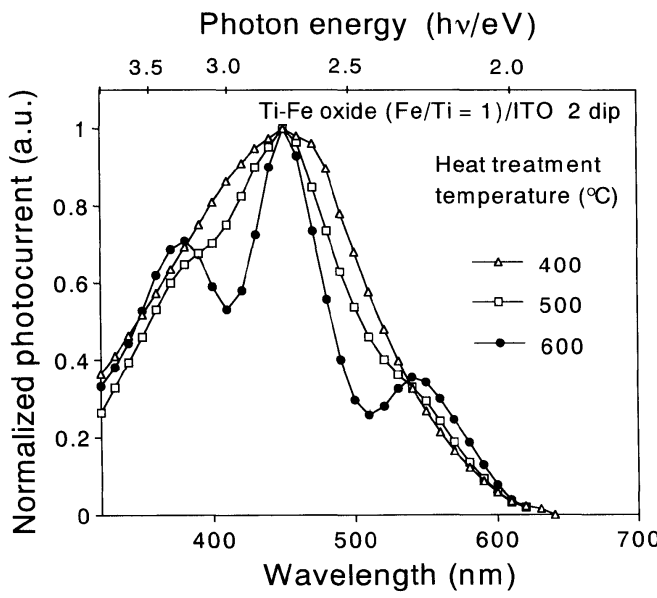

Fig.5 The variation of the photocurrent spectra with heat treatment temperature for the composition with the $\mathrm{Fe} / \mathrm{Ti}$ mole ratio of 1

extended to lower photon energy may correspond to the amorphous structure with $\mathrm{Fe} / \mathrm{Ti}$ mole ratio of 1 . For the specimen of $\mathrm{Fe} / \mathrm{Ti}$ mole ratio of 1 the variation of the photocurrent spectra with heat treatment temperature is shown in Fig. 5 . The photocurrent spectrum reveals a broad character for the specimen heat-treated at $400^{\circ} \mathrm{C}$ and $500^{\circ} \mathrm{C}$, while two more peak spectrum with smaller peak widths were detected for the specimen at $600^{\circ} \mathrm{C}$. The two peaks should be attributed to pseudobrookite and rutile phases as identified by $\mathrm{XRD}$ (in Fig. 2). A similar results were reported for the samples prepared by thermal
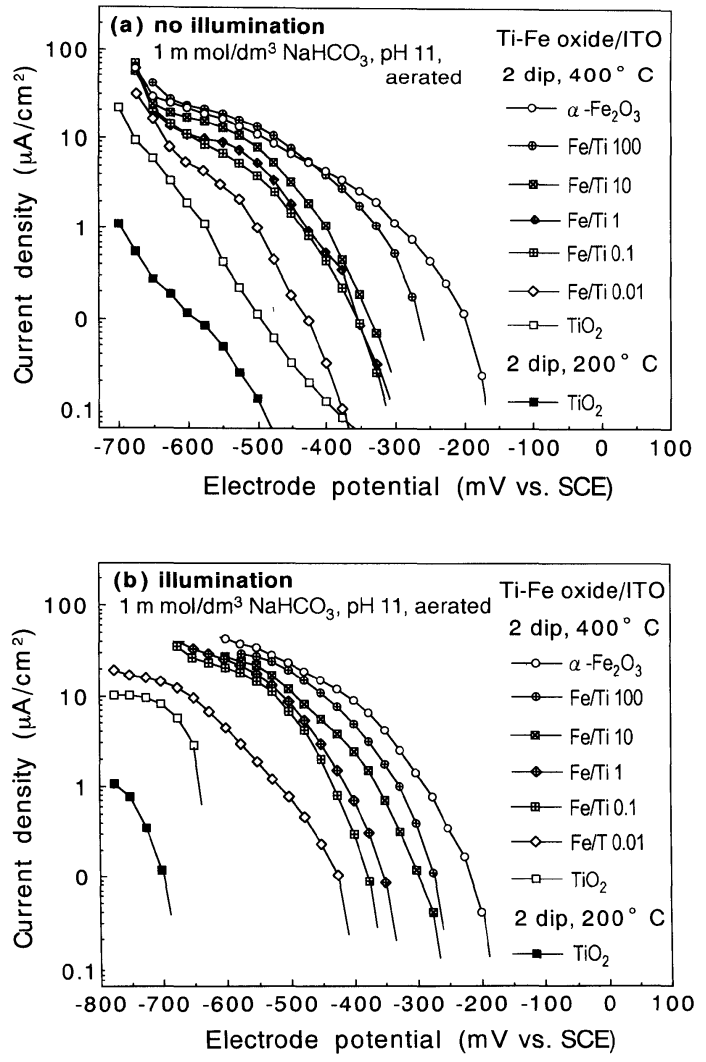

Fig.6 The cathodic polarization curves of Ti-Fe oxides under no illumination(a) and illumination (b).

decomposition of corresponding metal salt solutions ${ }^{11)}$.

\section{2.2 Oxygen reduction}

Fig. 6 shows the cathodic polarization curves of Ti-Fe oxides in aerated condition. The oxygen reduction currents increased with increasing $\mathrm{Fe}$ content in oxides, and the currents under illumination (Fig. 6 b) were larger than that without illumination (Fig. 6 a) as observed in our previous work. From the cathodic polarization curves of the pure $\mathrm{TiO}_{2}$ heat-treated at $400^{\circ} \mathrm{C}$ and $200^{\circ} \mathrm{C}$, it is found that the oxygen reduction was suppressed greatly for $\mathrm{TiO}_{2}$ heat-treated at $200^{\circ} \mathrm{C}$ where the oxide was amorphous.

\section{2. 3 Redox reaction of $\mathrm{Fe}^{2+} / \mathrm{Fe}^{3+}$ in $\mathrm{Ti}-\mathrm{Fe}$ oxides}

The measurements of cyclic voltammetry were carried out in order to understand the reduction and re-oxidation for different compositions of $\mathrm{Ti}-\mathrm{Fe}$ oxides. As shown by the 


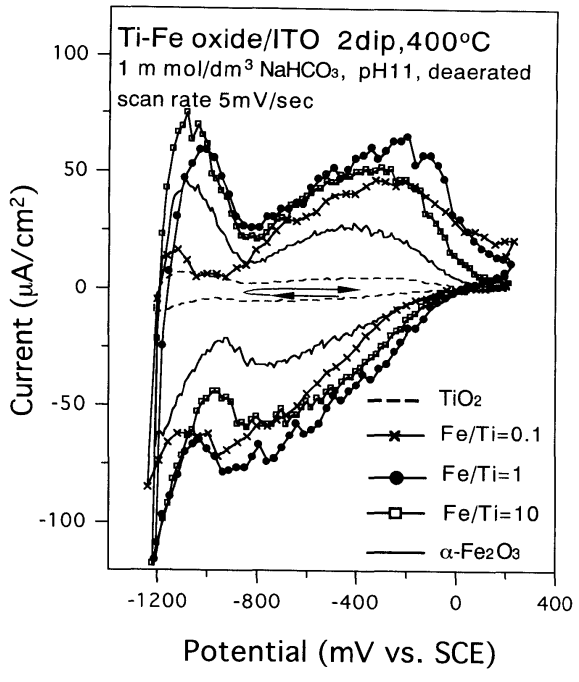

Fig.7 The cyclic voltammograms of TiFe oxides with different compositions under deaerated condition.

cyclic voltammograms in Fig. 7 , the reaction current for pure $\mathrm{TiO}_{2}$ is very low. In this deaerated condition, all the reduction and re-oxidation currents in the given potential should be of the redox reaction of $\mathrm{Fe}^{2+} / \mathrm{Fe}^{3+}$ in the oxides in addition to the hydrogen evolution. It was observed that reaction currents for intermediate range of composition were larger than that for pure $\alpha-\mathrm{Fe}_{2} \mathrm{O}_{3}$, and there appeared a largest reduction and re-oxidation currents for the amorphous Ti-Fe oxide with $\mathrm{Fe} / \mathrm{Ti}$ mole ratio of 1 . This means that the redox reaction of $\mathrm{Fe}^{2+} / \mathrm{Fe}^{3+}$ occurs easily in the intermediate range of composition.

\section{3 Structure and pho toeffect of a multi-} layer Ti-Fe oxide coating on carbon steel

\section{3. 1 An inner layer of $\alpha-\mathrm{Fe}_{2} \mathrm{O}_{3}$}

As shown in Fig. $3, \mathrm{TiO}_{2}$ (anatase) layer without $\mathrm{Fe}$ contamination exhibits a good photoeffect and even a small amounts of $\mathrm{Fe}$ contaminating $\mathrm{TiO}_{2}$ coating could result in a significant decline of photoeffect. A significant diffusion of $\mathrm{Fe}$ into $\mathrm{TiO}_{2}$ coating was found if $\mathrm{TiO}_{2}$ was directly coated on carbon stee ${ }^{4), 5}$. Thus it is imperative that we should introduce an interfacial layer between the steel substrate and $\mathrm{TiO}_{2}$ coating, which should acts as both a barrier to retard the diffusion of $\mathrm{Fe}$ into $\mathrm{TiO}_{2}$ and as a way for the
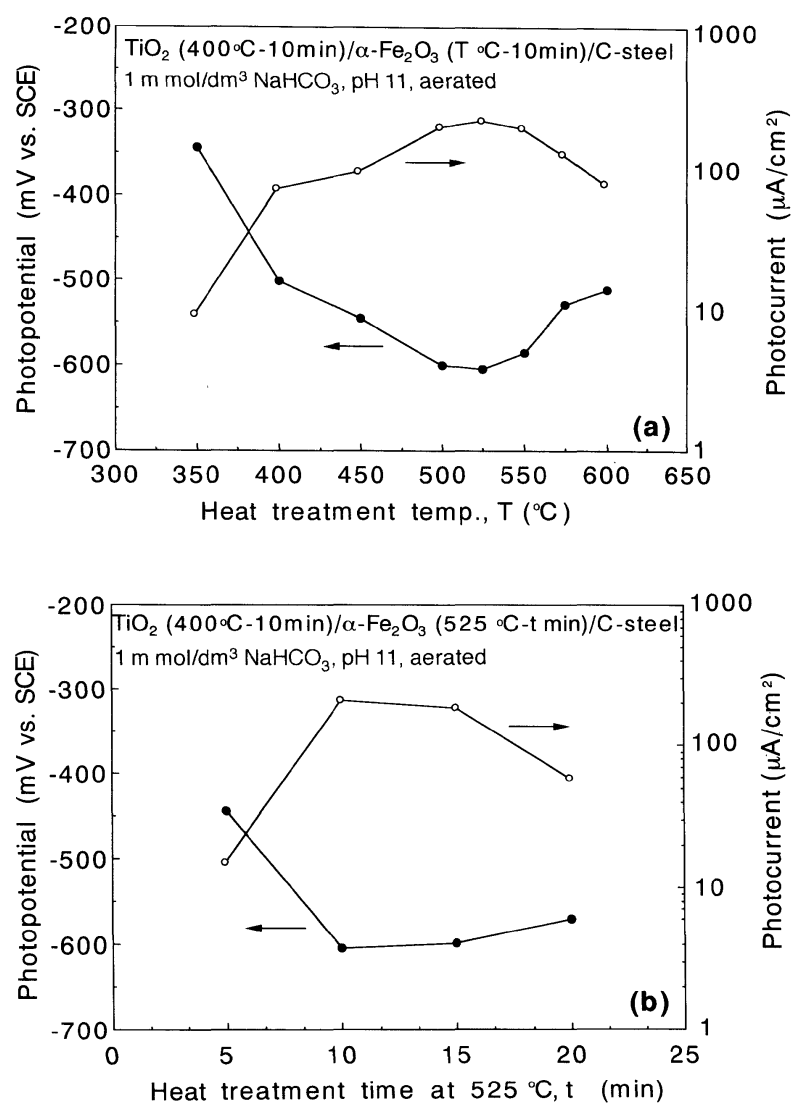

Fig.8 The relationship of the photoeffect in terms of photopotential and photocurrent (at $0 \mathrm{mV}$ vs. SCE) with heat treatment at temperature, $T$, for $10 \mathrm{~min}$ (a) and time, $t$, at $525^{\circ} \mathrm{C}$ (b) for $\alpha-\mathrm{Fe}_{2} \mathrm{O}_{3} / \mathrm{C}$-steel, followed by the one at $400^{\circ} \mathrm{C}$ for $10 \mathrm{~min}$ for the $\mathrm{TiO}_{2} / \alpha-\mathrm{Fe}_{2} \mathrm{O}_{3} / \mathrm{C}$-steel system.

transfer of photo-excited electrons from $\mathrm{TiO}_{2}$ coating to the substrate. Among different kinds of iron oxides which are probably formed on carbon steel in the process of coating and/or heat treatment for $\mathrm{TiO}_{2}, \alpha-\mathrm{Fe}_{2} \mathrm{O}_{3}$ exhibited a good performance ${ }^{5)}$. In the present work, a layer of $\alpha-\mathrm{Fe}_{2} \mathrm{O}_{3}$ on steel was prepared by sol-gel method. Fig. 8 shows the relationship of the photoeffect with heat treatment condition. The optimum heat treatment condition was found to be $525^{\circ} \mathrm{C}$ for $10 \sim 20 \mathrm{~min}$ for $\alpha-\mathrm{Fe}_{2} \mathrm{O}_{3} / \mathrm{C}$-steel followed by $400^{\circ} \mathrm{C}$ for $10 \mathrm{~min}$ for the $\mathrm{TiO}_{2} / \alpha-\mathrm{Fe}_{2} \mathrm{O}_{3} / \mathrm{C}$-steel system. The $\alpha$ $-\mathrm{Fe}_{2} \mathrm{O}_{3}$ was predominantly formed at the temperature of $525^{\circ} \mathrm{C}$ through the phase transformation of the sol-gel coating in addition to a little part of them from the oxidation of the substrate steel in coating defects. When 


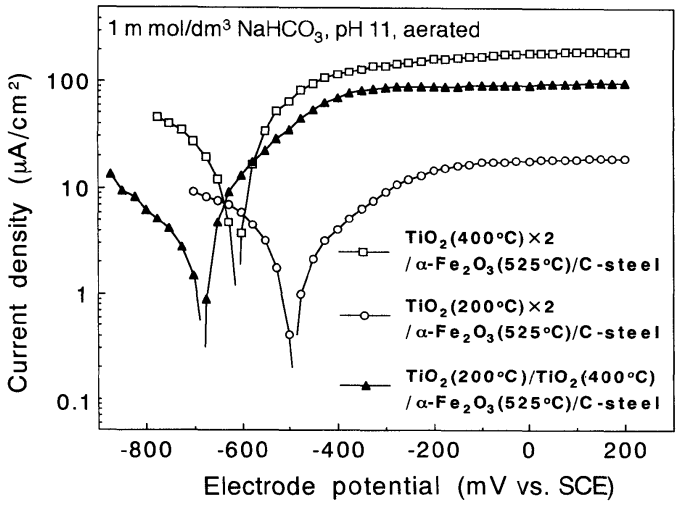

Fig.9 The polarization curves of coatings with an outer layer of amorphous $\mathrm{TiO}_{2}, \mathrm{TiO}_{2}$ $\left(200^{\circ} \mathrm{C}\right)$, or/and anatase $\mathrm{TiO}_{2}$.

heat-treated at lower temperatures, the sol-gel film could not transform completely from the $\gamma-\mathrm{Fe}_{2} \mathrm{O}_{3}$ and/or amorphous to $\alpha-\mathrm{Fe}_{2} \mathrm{O}_{3}$. On the other hand, for a higher temperature and a longer duration there would appear an iron oxide scale, which mainly consists of $\mathrm{Fe}_{3} \mathrm{O}_{4}$ and $\gamma-\mathrm{Fe}_{2} \mathrm{O}_{3}$.

\section{3. 2 An outer layer of amorphous $\mathrm{TiO}_{2}$}

Photopotential is determined both by the anodic photocurrent and by the cathodic current of oxygen reduction in aerated condition. As shown in Fig. 6, there is a low current of oxygen reduction for amorphous $\mathrm{TiO}_{2}$. Fig. 9 shows the polarization curves of $\mathrm{TiO}_{2}$ with different coating structures under illumination. By covering the crystalline $\mathrm{TiO}_{2}$ (anatase) coating with a layer of amorphous $\mathrm{TiO}_{2}, \mathrm{TiO}_{2}$ $\left(200^{\circ} \mathrm{C}\right)$, an improved photoeffect was achieved with a larger anodic photocurrent from the crystalline $\mathrm{TiO}_{2}$ (anatase) combined with a lower cathodic current from the outer layer of amorphous $\mathrm{TiO}_{2}$. For $\mathrm{TiO}_{2}$ (anatase) $/ \alpha-\mathrm{Fe}_{2} \mathrm{O}_{3} /$ C-steel, electrode potential after stopping illumination was found to recover to its original value before illumination relatively slowly in deaerated solution while quickly in aerated solution ${ }^{5}$. Fig. 10 shows the recovery of the electrode potential for the $\mathrm{TiO}_{2}$ (amorphous) $/ \mathrm{TiO}_{2}$ (anatase) $/ \alpha-\mathrm{Fe}_{2} \mathrm{O}_{3} / \mathrm{C}$-steel in aerated solution, where the phenomenon of slower recovery of electrode potential appeared because of the oxygen reduction suppressed by the outer layer of amorphous $\mathrm{TiO}_{2}, \mathrm{TiO}_{2}\left(200^{\circ} \mathrm{C}\right)$.

\section{3. 3 An intermediate layer of Ti-Fe oxide}

For a multi-layer structure with an inter-

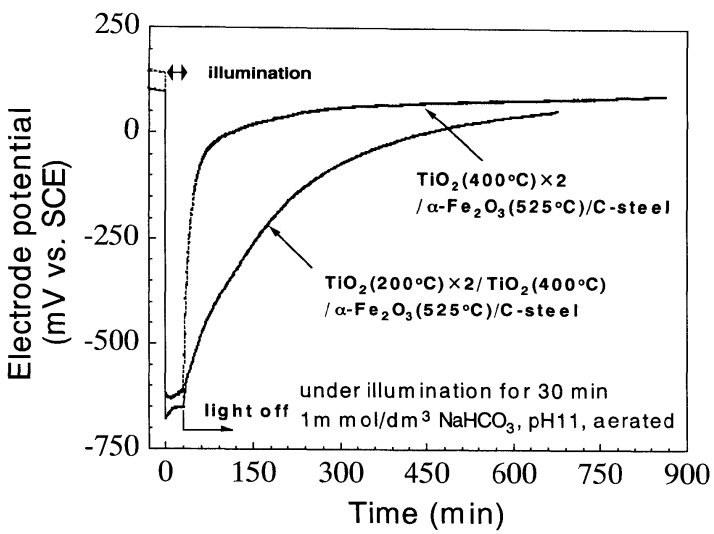

Fig.10 The recovery of the electrode potential with and without an outer layer of amorphous $\mathrm{TiO}_{2}$ after stopping illumination in aerated condition.

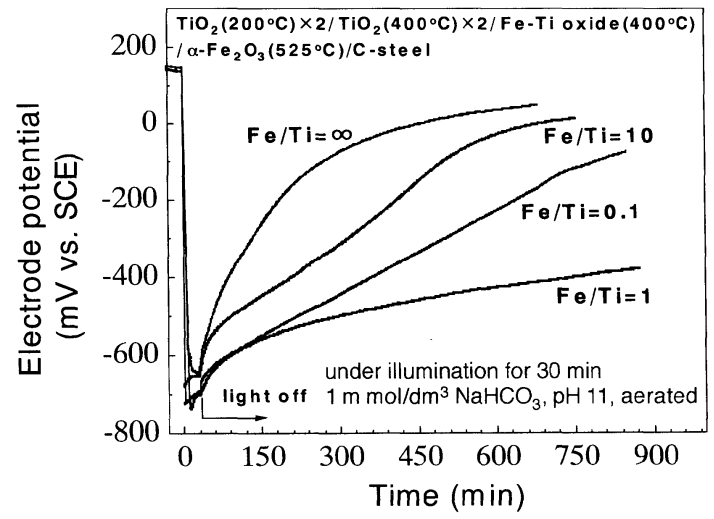

Fig.11 The effect of $\mathrm{Fe} / \mathrm{Ti}$ mole ratio for intermediate layer of Ti-Fe oxide on the recovery of the electrode potential after stopping illumination in aerated condition.

mediate layer of Ti-Fe oxide, expressed as from outer coating layer to substrate: $\mathrm{TiO}_{2}$ (amorphous) $/ \mathrm{TiO}_{2}$ (anatase) $/ \mathrm{Ti}-\mathrm{Fe}$ oxide $/ \alpha$ $\mathrm{Fe}_{2} \mathrm{O}_{3} / \mathrm{C}$-steel, the recovery of potential after 30 min of illumination are shown in Fig. 11. With an intermediate layer of amorphous $\mathrm{Ti}-\mathrm{Fe}$ oxide with $\mathrm{Fe} / \mathrm{Ti}$ mole ratio of 1 , the most slow recovery rate was observed; the potential after stopping the illumination was found to remain at $-450 \mathrm{mV}$ after $600 \mathrm{~min}$. Fig. 12 shows the effect of illumination duration on the recovery of the electrode potential. The recovery suppressed more longer with increasing illumination duration. Fig. 13 shows the effect of thickness of $\mathrm{TiO}_{2}$ (anatase). A 


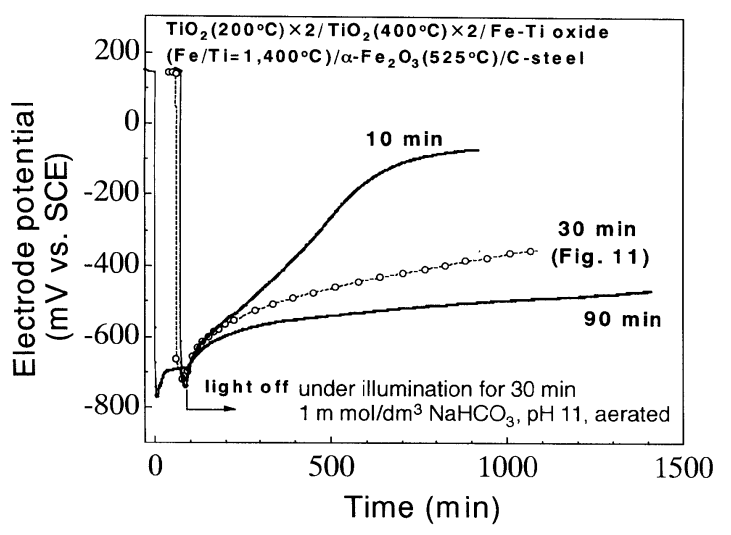

Fig.12 The effect of illumination duration on the recovery of the electrode potential after stopping illumination in aerated condition.

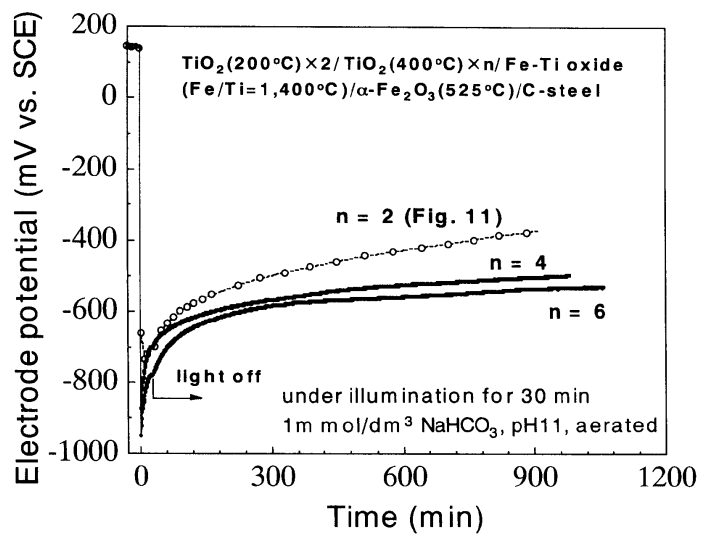

Fig.13 The effect of thickness of $\mathrm{TiO}_{2}$ (anatase) on the recovery of the electrode potential after stopping illumination in aerated condition.

more less noble value for the electrode potential after stopping illumination, for example, $-550 \mathrm{mV}$ after $600 \mathrm{~min}$, was obtained with increased thickness of $\mathrm{TiO}_{2}$ (anatase). As shown above, the phenomenon of the slower recovery of electrode potential should be related to the redox reaction of $\mathrm{Fe}^{2+} / \mathrm{Fe}^{3+}$ in intermediate $\mathrm{Ti}-\mathrm{Fe}$ oxide in addition to the oxygen reduction. Under illumination $\mathrm{Fe}^{3+}$ can be reduced to $\mathrm{Fe}^{2+}$ by the photo-electrons from $\mathrm{TiO}_{2}$ (anatase) layer, and the $\mathrm{Fe}^{2+}$ is re-oxidized to $\mathrm{Fe}^{3+}$ by oxygen reduction after stopping illumination. Increment of the amount of $\mathrm{Fe}^{2+}$, such as with a more reducible amorphous Ti-Fe oxide, enhancing photocurrent by increasing the thickness of $\mathrm{TiO}_{2}$ (anatase) coat- ing, and increasing illumination duration, would maintain the potential after stopping illumination at less noble for more longer time until all the $\mathrm{Fe}^{2+}$ is re-oxidized by oxygen reduction, which is inhibited by the outer layer of amorphous $\mathrm{TiO}_{2}$.

\section{Conclusions}

By studying the characteristics of the sol-gel derived Ti-Fe oxides and their influences on the photoeffect of $\mathrm{TiO}_{2} / \mathrm{C}$-steel system, a multi-layer coating, expressed as from outer coating layer to substrate: $\mathrm{TiO}_{2}$ (amorphous) / $\mathrm{TiO}_{2}$ (anatase) $/ \mathrm{Ti}-\mathrm{Fe}$ oxide $/ \alpha-\mathrm{Fe}_{2} \mathrm{O}_{3} / \mathrm{C}$-steel, was proposed for more effective photoelectrochemical cathodic protection of carbon steel. The intermediate layer of amorphous Ti-Fe oxide was shown to provide deep levels for $\mathrm{Fe}^{2+} / \mathrm{Fe}^{3+}$ redox couple, for which $\mathrm{Fe}^{3+}$ was reduced to $\mathrm{Fe}^{2+}$ under illumination. The state of $\mathrm{Fe}^{2+}$ left after stopping illumination maintained the electrode potential considerably less noble until all the $\mathrm{Fe}^{2+}$ was re-oxidized to $\mathrm{Fe}^{3+}$ by oxygen reduction. The outer layer of amorphous $\mathrm{TiO}_{2}$ inhibited the oxygen reduction to contribute to prolonged stay of the photopotential at less noble values.

(Manuscript received September 25, 1997; in final form November 4, 1997)

\section{References}

1) R. Fujisawa, T. Shinohara and S. Tsujikawa: Proc. of 40th Japan Corrosion Conf., 37(1993).

2) R. Fujisawa and S. Tsujikawa: Zairyoto-Kankyo, 43, 500 (1994).

3 ) J. Yuan and S. Tsujikawa: J. Electrochem. Soc., 142, 3444 (1994).

4) J. Yuan and S. Tsujikawa: Zairyo-toKankyo, 44, 534 (1995).

5 ) J. Huang, T. Shinohara and S. Tsujikawa: Zairyo-to-Kankyo, 46, 651 (1997).

6 ) T. Konishi and S. Tsujikawa: Zairyo-toKankyo, 46, 709 (1997).

7) T. Konishi and S. Tsujikawa:192nd Meeting of the Electrochemical Society (ECS), Paris (1997)

8 ) K. Kojima and M. Miyazaki: Journal of Sol-Gel Science and Technology, 8, 77 (1997).

9 ) M. Macek and B. Orel: Journal of Sol-Gel Science and Technology, 8, 771 (1997).

10) $\mathrm{Y} . \mathrm{Wu}, \mathrm{L} . \mathrm{Hu}, \mathrm{Z}$. Jiang and Q. Ke : J. Electrochem. Soc., 144, 1728 (1997).

11) B. Danzfuss and U. Stimming: J. Electroanal. Chem., 164, 89 (1984). 